\title{
Phagocytosis and killing of bacteria and yeast by human milk cells after opsonisation in aqueous phase of milk
}

\author{
J E ROBINSON, B A M HARVEY, J F SOOTHILL
}

British Medical fournal, 1978, 1, 1443-1445

\section{Summary and conclusions}

Macrophages and neutrophils from human milk phagocytose and kill Staphylococcus aureus and Escherichia coli in vitro after opsonisation by the aqueous phase of milk as effectively as blood leucocytes in serum. They also phagocytose Candida albicans. The overgrowth of $E$ coli resulting from the addition of iron to cultures of the organism in the aqueous phase of milk is not influenced by the presence of cells.

We conclude that the phagocytosis and killing of bacteria by milk cells may contribute to the lower incidence of infection among breast-fed than artificially fed babies.

\section{Introduction}

A lower incidence of infection occurs among breast-fed babies than among artificially fed babies, ${ }^{1}$ and there are large differences in the faecal flora, Escherichia coli being the predominant organism in artificially fed babies." Much of the antibacterial effect of milk has been ascribed to the powerful bacteriostatic function of fluid-phase components, including buffer, lactoferrin, and IgA antibody. ${ }^{3}$ Lysozyme, a humoral bactericidal substance, is also present. The main bactericidal activity of blood is opsonisation preparatory to phagocytosis by polymorphonuclear neutrophilic leucocytes (neutrophils) and macrophages, which are present in human milk. ${ }^{*}$ The only reports of in-vitro function of human milk cells, however, have concerned the phagocytosis of heat-killed Staphylococcus aureus ${ }^{4}$ and Cryptococcus neoformans. ${ }^{5}$ Studies on rats have shown that milk cells can protect against experimental enterocolitis. ${ }^{6}$ We therefore studied the phagocytosis and killing by human-milk neutrophils and macrophages of the common neonatal pathogens Staph aureus, E coli, and Candida albicans in media containing either serum or the aqueous phase of milk.

\section{Methods}

Milk collection-Milk samples were obtained in the morning, usually at the end of a feed, from lactating mothers between the third and tenth days of lactation (one sample excepted). Manual expression or a breast pump was used and the milk was collected into sterile plastic containers. The samples were kept at room temperature and analysed within two hours. Plastic containers were used throughout. Cell separation-Samples were centrifuged (MSE 2L centrifuge) at $200 \mathrm{~g}$ for 30 minutes at $4^{\circ} \mathrm{C}$. In limited preliminary studies lower yields had been obtained with 10 minutes' centrifugation, centrifugation after initial milk dilution, and membrane filtration using a $3 \mu \mathrm{m}$ Millipore filter. During centrifugation the milk separated into three layers-namely, a cell pellet, middle layer, and fat layer. After the

\footnotetext{
Department of Immunology, Institute of Child Health, University of London, London WC1N 1EH

J E ROBINSON, MB, DCH, lecturer

B A M HARVEY, FIMLS, chief technician

J F SOOTHILL, FRCP, FRCPATH, professor of immunology
}

middle and fat layers had been removed the cell pellet was washed, resuspended in Hanks's tissue culture medium, and counted in a haemacytometer. The middle-layer samples were hard spun at $1500 \mathrm{~g}$ for 15 minutes at $4^{\circ} \mathrm{C}$ to obtain aqueous-phase milk, which was used for opsonisation. Neutrophils from heparinised (preservativefree) blood taken from healthy staff were separated by $6 \%$ dextran sedimentation. The cells were washed, resuspended in Hanks's tissue-culture medium, and counted in a haemacytometer. Smears were prepared and stained with May-Grünwald-Giemsa and occasionally stained for non-specific esterase activity. ${ }^{\text {? }}$

Phagocytosis and killing of bacteria and yeast-A modification of the bactericidal method of Quie et $a l^{8}$ was used. About $10^{6}$ cells and $10^{7}$ bacteria in $1 \mathrm{ml}$ Hanks's medium containing $20 \%$ of the opsonising material were incubated at $37^{\circ} \mathrm{C}$ for 20 minutes. After centrifugation the cell pellet was resuspended in Hanks's medium containing penicillin and streptomycin, and a $0.16 \mathrm{ml}$ aliquot was removed. The remainder was incubated for a further two hours, after which a second $0.16 \mathrm{ml}$ aliquot was taken (140-minute count). The cells in each aliquot were centrifuged, washed, and disrupted by vigorous pipetting; the colonies formed by the released phagocytosed organisms were counted by duplicate pour plates at two suitable dilutions after overnight culture. The 20-minute count provided a measure of phagocytosis. Killing was measured by calculating the 140-minute count/20-minute count. Preliminary studies had suggested that these times, suitable for blood cells, were also appropriate for milk cells. A non-pathogenic strain of $E$ coli, obtained from a child's faecal culture, and the Oxford strain of Staph aureus were used; both were sensitive to penicillin and streptomycin. In some samples smears were prepared from the 20-minute aliquots and stained with Giemsa. The phagocytosis and killing of $C$ albicans were studied by means of a vital-dye method, 9 in which $10^{5}$ milk cells and $10^{5}$ organisms from a three-day culture were used in $0.3 \mathrm{ml}$ HEPES medium and $0.1 \mathrm{ml}$ of either serum or aqueous-phase milk. Cultures were examined hourly for five hours.

Iron and bactericidal effect of milk cells-About $500 \mathrm{E}$ coli were incubated in $0.5 \mathrm{ml}$ (total volume) aqueous-phase milk to which milk cells $\left(0.7 \times 10^{6}-3.0 \times 10^{6}\right)$ or $10 \mu \mathrm{g}$ iron (ferric ammonium citrate) or both or neither had been added. Separate cultures were counted at one, two, three, and four hours; they were vigorously pipetted to disrupt any cells that were present, and bacteria in the whole culture were counted as described above.

Statistical analysis was carried out with the Wilcoxon-White rank sum test.

\section{Results}

Cell counts-The nucleated cell counts of resuspended cell pellets were expressed in terms of the volume of the original milk sample; the mean value for 17 samples was $4.13 \times 10^{5}$ cells $/ \mathrm{ml}$ milk (range $2.5 \times 10^{4}-1.6 \times 10^{6} / \mathrm{ml}$ ). Since cells were seen in stained smears of the fat and middle layers, this was less than the total cell count of the milk. Neutrophils (20-80\%), macrophages, lymphocytes, and eosinophils $(12 \%$ in one sample) were identified in stained films from the six samples that were morphologically sufficiently preserved (see fig 1). Identification was difficult in the other 11 samples largely because of the fat content of the cells. In selected samples the identification of macrophages was confirmed by non-specific esterase staining.

Phagocytosis and killing of $S$ aureus and E coli-Stained films of the 20-minute aliquots of cultures of bacteria, milk cells, and medium containing aqueous-phase milk showed numerous Staph aureus and $E$ coli in many macrophages and neutrophils (fig 1). Counts of Staph aureus in cells after the 20-minute culture showed that phagocytosis by milk cells in milk medium was as effective as that by blood cells in serum medium and by milk cells in serum medium $(P>0.05)$; blood cells in milk medium were less effective than blood cells in serum $(\mathrm{P}<0.05$; figs 2 and 3$)$. Milk cells in milk medium also killed as effectively as blood cells in serum medium. Milk cells in serum medium and blood cells in milk medium were similarly effective $(\mathbf{P}>0.05$ for each comparison). Phagocytosis and killing of $E$ coli by all four 
combinations of cells in media were similar, although fewer organisms (range $5 \times 10^{3}-1.5 \times 10^{5}$ ) were phagocytosed than was the case with Staph aureus. We excluded the possibility that the apparent killing was an effect of the entry of humoral bactericidal substances or antibiotics into the cells by showing that killing was an active function of the cell. Sodium azide $10 \mathrm{mmol} / 1(65.4 \mathrm{mg} / 100 \mathrm{ml})$, which inhibits bacterial killing without affecting phagocytosis, had little effect on phagocytosis (20-minute count) but partially suppressed killing (table I).

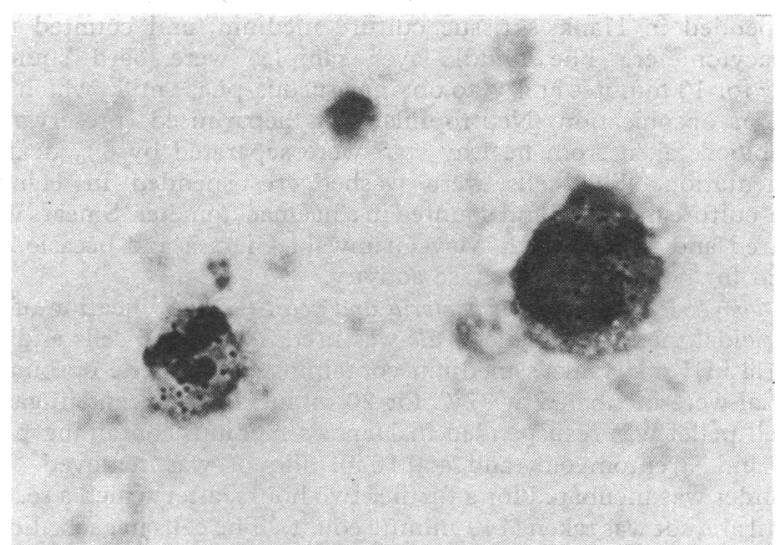

FIG 1-Human milk cells after culture in vitro with Staph aureus stained with Giemsa and showing phagocytosis by neutrophil and monocyte. Some ingested fat also present. $(\times 200$.)

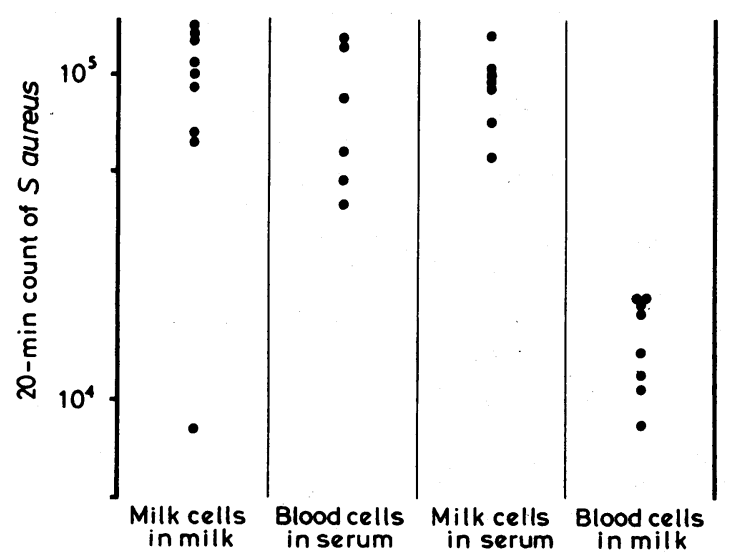

FIG 2-Phagocytosis of bacteria by milk cells. Counts of intracellular Staph aureus after culturing bacteria for 20 minutes with human milk cells or blood neutrophils in media containing serum or aqueous-phase milk.

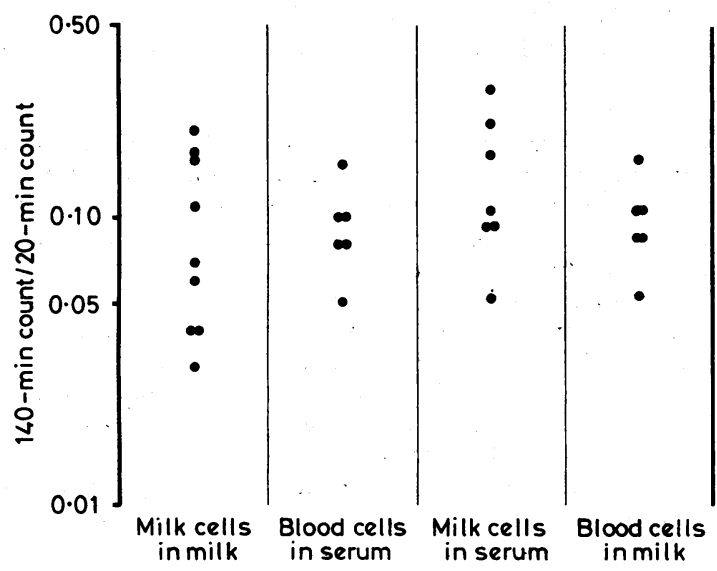

FIG 3-Killing of phagocytosed bacteria by milk cells: measure of killing of Staph aureus (140-min count/20-min count) by milk or blood cells in serum or milk-containing media (as fig 2). Value of one would indicate no killing; lower values indicate better killing.
TABLE I-Phagocytosis and killing of Staph aureus and E coli by human milk cells in aqueous-phase milk with or without sodium azide $10 \mathrm{mmol} / \mathrm{l}(65.4 \mathrm{mg} /$ $100 \mathrm{ml}$ )

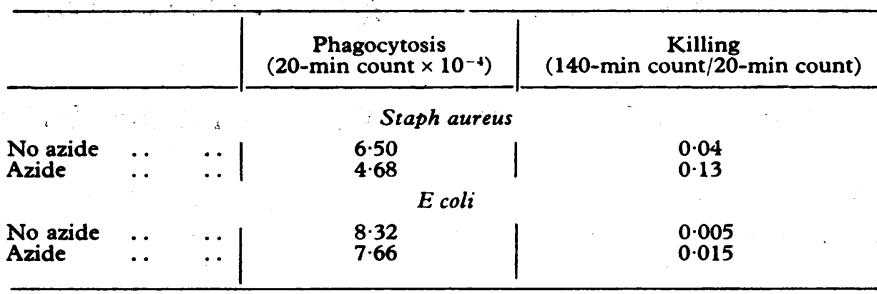

TABLE II-Phagocytosis and killing-that is, failure to take up vital dye-of $C$ albicans by human milk cells (six samples) after two hours' culture in medium containing autologous aqueous-phase milk

\begin{tabular}{ll|c|c}
\hline & & $\begin{array}{c}\text { Phagocytosis } \\
\text { (No of candida/100 cells) }\end{array}$ & $\begin{array}{c}\text { Killing } \\
\text { (") phagocytosed candida not stained) }\end{array}$ \\
\hline $\begin{array}{ll}\text { Mean } \\
\text { Range }\end{array}$ & $\cdots$ & $\begin{array}{c}232 \\
0.1 \cdot 2\end{array}$ \\
\hline
\end{tabular}
TABLE III-Phagocytosis of C albicans by human milk cells (four samples) cul-

\begin{tabular}{|c|c|c|c|}
\hline & & \multicolumn{2}{|c|}{ No of candida $/ 100$ cells } \\
\hline & & Mean & Range \\
\hline $\begin{array}{l}\text { Medium with aqueous-phase milk } \\
\text { Medium only } \ldots\end{array}$ & $\because$. & $\begin{array}{r}170 \\
44\end{array}$ & $\begin{array}{c}120-250 \\
9-80\end{array}$ \\
\hline
\end{tabular}

Phagocytosis and killing of $C$ albicans-Many $C$ albicans were phagocytosed by milk cells (both neutrophils and macrophages) after two hours' incubation in a milk-containing medium (table II), but few were killed then or after five hours' culture. Milk cells in medium alone phagocytosed less well than parallel cultures in milk medium, confirming that milk opsonises $C$ albicans (table III). These parallel $\overrightarrow{\vec{O}}$ studies of different combinations of cells and opsonising media from 3 the same donor, carried out to elucidate the factors contributing to the failure of cells to kill candida, were limited by the numbers of cells available. In four such cultures, however, milk cells in serumcontaining media phagocytosed many candida but killed less than $1 \%$, whereas the mean killing for blood cells in milk medium was $4 \%$ and for blood cells in blood $15 \%$. It therefore appears that although aqueous-phase milk and milk cells opsonise or phagocytose candida effectively, they are not as effective as serum or blood cells.

Iron and bactericidal effect of milk cells-When $E$ coli were cultured in the aqueous piase of milk from three samples, with or without autologous cells and with or without iron, overgrowth of $E$ coli occurred at four hours in:iron-containing cultures whether cells were present or $\mathrm{N}$ not (fig 4).

\section{Discussion}

Our cell counts confirm that large numbers of neutrophils and monocytes are present in human milk. ${ }^{4}$ In-vivo studies ${ }^{6}$ suggest that the cells of rat milk protect against hypoxically induced $\mathscr{D}$ enterocolitis in formula-fed rats, but there have been few reports of the in-vitro function of milk cells or the opsonising function of aqueous-phase milk. Cells in bovine milk phagocytose C albicans, ${ }^{10}$ but work on human cells has been confined to the phagocytosis of killed Staph aureus and $\mathrm{Cr}$ neoformans, using serum-containing media. ${ }^{45}$ This contrasts with the extensive work on the bacteriostatic and bactericidal effects of the aqueous phase. $^{3}$

We found that human-milk cells phagocytosed and killed Staph aureus and $E$ coli, and phagocytosed $C$ albicans; and all $\rightleftharpoons$ three organisms were effectively opsonised by the aqueous phase. The opsonisation is consistent with the presence in milk of immunoglobulin ${ }^{11}$ and a range of components of the classical and alternative pathways of complement and of effective immune 


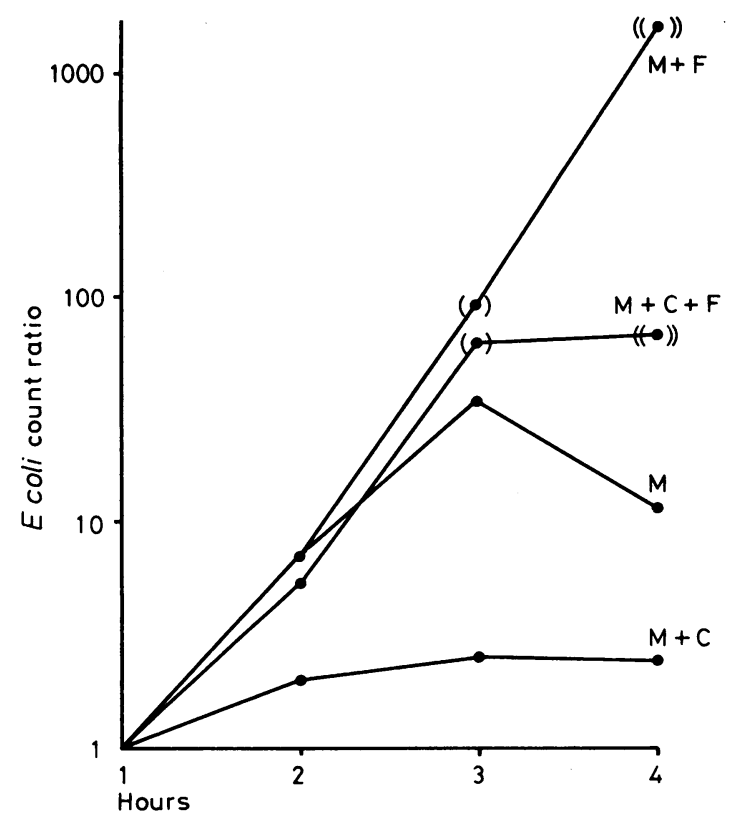

FIG 4-Effect of iron on bacterial growth in milk: $E$ coli count ratios after culture in aqueous-phase human milk (M) with or without iron $(F)$ and milk cells $(C)$ plotted against time of culture in hours. (Duplicate counts made of three samples from different mothers.) $E$ coli count ratios calculated from mean counts at each time/mean count at one hour. Values plotted as (9) included results greater than upper limit of countable bacteria $\left(5 \times 10^{5} / \mathrm{ml}\right.$, an assigned value); values plotted as ( (O) ) composed entirely of such threshold results.

adherence. ${ }^{12}$ The opsonisation of bacteria presumably depends on immunoglobulin and the classical pathway of complement, but that of $C$ albicans may depend on the alternative pathway. The less effective killing of $C$ albicans after phagocytosis by blood cells in milk medium as compared with blood cells in serum may result from inadequate complement activation, since killing is more complement-dependent than opsonisation. ${ }^{13}$
The less effective killing by milk cells may be caused by the phagocytosed lipid. The powerful humoral bacteriostatic effect of milk, dependent on IgA antibody and lactoferrin, is inactivated by the addition of iron. ${ }^{3}$ Our data suggest that the bactericidal effect of milk cells is also negligible when iron is added but could contribute significantly in the normal iron-free state, as is indicated by in-vivo experiments. ${ }^{6}$ These also suggest that the cells survive in the gastrointestinal tract long enough to produce an effect.

Epidemiological studies have shown that breast-fed babies are less susceptible to infection than artificially fed babies. ${ }^{1}$ Our results establish a further mechanism for this and strengthen the case against the use of iron-containing complementary feeds. ${ }^{3}$ There is little prospect of replacing cells in bovine-milk feeds, and our findings raise further problems in planning breast-milk banks.

We thank our colleagues, and the mothers at the Mothers' Hospital for the samples.

\section{References}

${ }^{1}$ Hanson, L A, and Winberg, J, Archives of Disease in Childhood, 1972, 47, 845.

${ }^{2}$ Bullen, C L, and Willis, A T B, British Medical fournal, 1971, 3, 338.

${ }^{3}$ Bullen, J J, in Acute Diarrhoea in Childhood, Ciba Foundation Symposium No 42, ed K Elliott. Amsterdam, Elsevier, 1976.

4 Smith, C, and Goldman, A, Pediatric Research, 1968, 2, 103.

5 Mohr, J A, Leu, R, and Mabry, W, Fournal of Surgical Oncology, 1970, 2, 163.

${ }^{6}$ Pitt, J, et al, Pediatric Research, 1974, 8, 384.

${ }^{7}$ Dacie, J V, and Lewis, S M, Practical Haematology, 5th edn. London, Churchill Livingstone, 1975.

${ }^{8}$ Quie, P G, et al, fournal of Clinical Investigation, 1967, 46, 668.

${ }^{9}$ Lehrer, R I, and Cline, M J, Fournal of Bacteriology, 1969, 98, 996.

${ }^{10}$ Paape, M J, Schultze, W D, and Miller, R H, Fournal of Dairy Science, 1973, 56, 733.

11 Ammann, A J, and Stiehm, E R, Proceedings of the Society for Experimental Biology and Medicine, 1966, $122,1098$.

12 Ballow, M, et al, Clinical and Experimental Immunology, 1974, 18, 257.

13 Yamamura, M, and Valdimarsson, $\mathrm{H}$, Scandinavian fournal of Immunology, 1977, 6, 593.

(Accepted 28 March 1978)

\title{
Plasma arginine vasopressin concentrations and antidiuretic action of carbamazepine
}

\author{
W P STEPHENS, J Y COE, P H BAYLIS
}

British Medical fournal, 1978, 1, 1445-1447

\section{Summary and conclusions}

Twelve subjects given therapeutic doses of carbamazepine showed no change in their plasma electrolyte concentrations. Ten of the 12 had abnormal water metabolism, however, their ability to excrete water loads being

Good Hope General Hospital, Sutton Coldfield, West Midlands W P STEPHENS, MB, MRCP, medical registrar

J Y COE, $M B$, BS, senior house officer in medicine

Department of Medicine, Queen Elizabeth Hospital, Birmingham B15 2TH

P H BAYLIS, BSC, MRCP, senior registrar (present address: Department of Medicine, Veterans Administration Hospital, Indianapolis, USA) decreased. Plasma arginine vasopressin (AVP) concentrations fell while the subjects were taking the drug, indicating that the mechanism is unlikely to be increased secretion of antidiuretic hormone.

We suggest that the water-retaining property of carbamazepine is a physiological effect of the drug, mediated by increased renal sensitivity to normal plasma concentrations of AVP and resetting of osmoreceptors.

\section{Introduction}

The antidiuretic action of carbamazepine was recognised after reports on its use in diabetes insipidus and isolated cases of water intoxication during treatment with the drug. ${ }^{1}$ The mechanism of the action is not clear, and, whereas some reports suggest that asymptomatic electrolyte disturbances are fairly common, ${ }^{2}$ others suggest that they are rare. ${ }^{3}$ Previous studies have not shown whether carbamazepine affects the water metabolism of 